\title{
PELATIHAN PEMBELAJARAN PENJAS YANG MENARIK DENGANMETODE PROGRESS CARD MELALUI CIRCUIT TRAININGDANLADDER DRILL
}

\author{
Yudo Harvianto dan Bernisa \\ Pendidikan Jasmani, Kesehatan dan Rekreasi, FKIP Universitas Palangka Raya \\ e-mail : yudo@fkip.upr.ac.id
}

\begin{abstract}
Abstrak; Pembelajaran merupakan sebuah proses interaksi pendidikan yang terjadi antara pendidik dan peserta didik, yang tersusun secara sistematis dan terstruktural guna memberikan ilmu kepada peserta didik. Sedangkan pendidikan jasmani merupakan suatu proses pendidikan yang direncanakan secara sistematis dan struktur, dengan memanfaatkan aktivitas fisik yang bertujuan utamanya guna menjaga dan meningkatkan kebugaran tubuh. Metode progress cards merupakan sebuah metode pemebelajaran pendidikan jasmani modern yang inovatifkarena dikembagkan dari model-model latihan. Dengan adanya tambahan alat bantu yang memotivasi berupa progress carad (kartu kemajuan), merupakan sebuah usaha pengembangan kreatifitas tenaga pendidik. Selain itu juga akan memotivasi siswa untuk terlibat dalam proses pembelajaran. Kegiatan ini merupakan proses pelatihan yang hasilnya dapat langsung dilihat disaat para peserta mempraktekkan tugasnya dihadapan peserta lainnya. Dalamkegiatan ini peserta antusias mengikuti pelatihan, hal ini dapat dilihat dari perhatian peserta disaat memperhatikan dan menyimak disaat pemateri memberikan pemaparan secara teori maupun demonstrasi, selain itu juga begitu banyak pertanyaan-pertanyaan yang dilontarkan peserta disaat sesi tanya jawab. Kemudian disaat peserta diberikan tugas untuk membuat sebuah circuit training yang menarik dengan metode progress card melalui circuit trainingdan ladder drill, mereka cukup berhasil. Hal ini dapat dilihat disaat para peserta menjelaskan dan mendemonstrasikannya serta mempraktekkan kepada peserta lainnya. Selain itu juga bahwa peserta merasa senang mengiktui pelatihan ini karena menambah wawasana mereka tentang metode suata proses pembelajaran terutama dalam pendidikan jasmani. Dan juga dengan pelatihan ini peserta merasa bahwa kreativitas mereka dirangsang kembali dalam mengerjakan tugas yang telah diberikan.
\end{abstract}

Kata Kunci : Pembelajaran, Pendidikan Jasmani, Progress Cards

\section{PENDAHULUAN}

Dalam Undang-Undang No.20 Tahun 2003tentang Sistem Pendidikan Nasionalpasal1 ayat 20dinyatakan bahwapembelajaranadalah proses interaksi peserta didik dengan pendidik dan sumber belajar pada suatu lingkungan belajar. Dalam pembelajaran ini pendidik membuat sebuah rancangan proses belajar mengajar untuk capain tujuan tertentu. Selain itu bahwa pembelajaaran merupakan suatu proses transfer ilmu dan pengetahuan dari pendidik kepada peserta didik.

Sedangkan menurut Syaiful Sagala, (2011: 62) pembelajaran adalah kegiatan guru secara terprogram dalam desain instruksional, untuk membuat belajar secara aktif, yang menekankan pada penyediaan sumber belajar. Berdasarkan keterangan diatas, dapat disimpulkan bahwa pembelajaran adalah suatu proses interaksi antara peserta didik dengan pendidik pada lingkungan belajar yang tersusun secara sistematis dan struktural, untuk memberikan ilmu dan pengetahuan kepada peserta didik.

Dalam proses pembelajaran, salah satu mata pelajaran yang harus dipelajari oleh peserta didik, dan diajarakan oleh pendidik adalah mata pelajaran pendidikan jasmani.Pendidikan jasmani adalah suatu proses pembelajaran yang dilakukan secara sistematis melalui dan didominasi oleh aktivitas fisik dengan tujuan untuk mendapatkan kebuagaran jasmani.

Pembelajaran pendidikan jasmani selayaknya dimulai pada tahap usia dini, hal ini dikarenakan untuk merangsang pertumbuhan organik, motorik, intelektual dan perkembangan emosional (Solihin, Faisal, \& Dadang, 2013). Sedangkan menurut (Utama Bandi, 2011) pendidikan jasmani merupakan 
bagian yang tidak terpisahkan dari pendidikan nasional yang bertujuan untuk pengembangan kemampuan peserta didik melalui aktivitas jasmani. Melalui pendidikan jasmani juga dapat membantu peserta didik dalam pertumbuhan fisik, perkembangan kognitif, keterampilan motorik, serta kematangan afektif.

Mahasiswa yang dipersiapkan sebagai calon guru, diharapkan memiliki pengetahuan dan keterampilan yang matang, agar nantinya disaat menjadi seorang guru akan menjadikan proses pembelajaran berjalan dengan sukses. Namun faktanya bahwa masih banyak mahasiswa semester atas, belum matang dalam melakukan microteaching. Secara khusus kelemahan mereka yaitu menampilkan media pembelajaran yang menarik bagi siswa. Hal iniakan mengurangi motivasi peserta didik dalam mengikuti proses belajar mengajar. Menurut Sriawan dkk (2011: 3), seorang guru dapat menjadikan model permainan sebagai media pembelajaran dalam proses belajar mengajar, sehingga diharapkan dapat menjadi guru yang kreatif dan produktif serta mampu melaksakan tugas mengajar, dengan suasana yang menarik, menyenangkan, dan menggembirakan.

Berdasarkan latar belakang itulah, penulis tertarik melakukan pengabdian tentang pelatihan pembelajaranpenjas yang menarik dengan metode progress card melalui circuit training dan ladder drill.

Tujuan Kegiatan, dengan adanya kegiatan ini akan meningkatkan kreatifitas mahasiswa dalam memodifikasi permainan dalam pembelajaran.

\section{TINJAUAN PUSTAKA} Jasmani

Pengertian Pembelajaran Pendidikan

Belajar merupakan suatu proses interaksi yang telah dilalui oleh seseorang dengan lingkungannya guna memperoleh pengetahuan sehingga dapat mempengaruhi sikapnya. Menurut Sugihartono, dkk. (2013: 74) mendefinisikan belajar dalam dua pengertian.Pertama, belajar sebagai proses memperoleh pengetahuan dan kedua, belajarsebagai perubahan kemampuan bereaksi yang relatif langgeng sebagai hasillatihan yang diperkuat. Menurut Sugihartono, dkk. (2013: 74) pula mendefinisikan tentang pembelajaran, bahwa pembelajaran dalam arti umum dapat diartikan sebagai perubahanperilaku yang relatif tetap sebagai hasil dari proses pembelajaran itu sendiri. Serta upaya yang dilakukan dengan sengaja oleh pendidik yang dapat menyebabkan peserta didik melakukan kegiatan belajar.

Sedangkan menurut Asep (2012:12) mengatakan bahwapembelajaran adalahinti dari proses pendidikan secara keseluruhan dengan guru sebagai pemegang peranan utama. Pembelajaran merupakan suatu proses yang mengandung serangkaian perbuatan guru dan siswa atas dasar hubungan timbal balik yang berlangsung dalam situasi edukatifuntuk mencapai tujuan tertentu. Lain halnya dengan Wragg (2012:12) mengatakan pembelajaran yang efektif adalah pembelajaran yang memudahkan siswa untuk mempelajari sesuatu yang bermanfaat seperti fakta, keterampilan, nilai, konsep, dan bagaimana hidup serasi dengan sesama, atau suatu hasil belajar yang diinginkan.

Berdasarkan penjelasan diatas, dapat disimpulkan bahwa pembelajaran merupakan suatu interaksi yang telah terjadi antara pendidik dan peserta didik dalam lingkungan belajar dengan tujuan untuk mempelajari sesuatu yang bermanfaat seperti mentransfer ilmu dan pengetahuan guna mendapatkan keterampilan serta dapat merubah sikap peserta didik tersebut.

Kurikulum telah mendefinisikan pendidikan jasmani merupakan bagian integral dari sistem pendidikansecara keseluruhan, yang bertujuan untuk mengembangkan aspek kebugaranjasmani, keterampilan gerak, keterampilan berpikir kritis, keterampilansosial, penalaran, dan pengendalian emosional yang direncanakan secara sistematisdalam rangka mencapai tujuan pendidikan nasional.

Sedangkan Pendidikan Jasmani menurut Rosdiani (2013: 23) "Pendidikan Jasmani adalah proses pendidikan yang memanfaatkan aktivitas jasmani yang direncanakan secara sistematik bertujuan untuk mengembangkan dan meningkatkan individu secara organik, neumuskuler, perseptual, kognitif, dan emosional, dalam kerangka sistem pendidikan nasional". 
Pendapat lain dikemukakan oleh Cholik dan Lutan dalam Helmy Firmansyah (2009: 41) bahwa pendidikan jasmani adalah proses pendidikan yang melibatkan interaksi antara peserta didik dengan lingkungan yang dikelola melalui aktivitas jasmani secara sistematik menuju pembentukan manusia seutuhnya.Pembelajaran pendidikan jasmani dimulai pada tahap usia dini untuk merangsang pertumbuhan organik, motorik, intelektual dan perkembangan emosional (Solihin, Faisal, \& Dadang, 2013). Sedangkan menurut (Utama Bandi, 2011) pendidikan jasmani merupakan bagian yang tidak terpisahkan dari pendidikan nasional yang bertujuan untuk pengembangan kemampuan peserta didik melalui aktivitas jasmani. Melalui pendidikan jasmani juga sangat dapat membantu peserta didik dalam pertumbuhan fisik, perkembangan kognitif, keterampilan motorik.

Apabila disimpulkan dari beberapa penjelasan diatas, pendidikan jasmani adalah suatu proses pembelajaran yang dilakukan secara sistematis melalui dan didominasi oleh aktivitas fisik dengan tujuan untuk mendapatkan kebugaran jasmani, pertumbuhan fisik, perkembangan kognitif, keterampilan motorik dan kematangan afektif.

\section{Pengertian Progress Card}

Menurut Suroto (2008: Video Pembelajaran Aktifitas Pengembangan), secara teoritis, mata pelajaran penjas bisa mencapai aspek kognitif, afektif, dan psikomotor. Tapi secara praktis, baru sebagian kecil guru penjas yang berhasil mencapai tiga aspek tadi. Menurut Suroto (2008) pula bahwa pada metode ini dikembangkan metode baru hasil pengembangan dari metode latihan yang lebih mengutamakan ketangkasan dan keterampilan dari apa yang telah dipelajari dan dipadukan dengan menambah alatbantu penilaian hasil pembelajaran berupa sebuah kartu kemajuan (progress cards) hasil pembelajaran penjas yang dibawa siswa setiap kali kegiatan pembelajaran penjas yang diharapkan dapat meningkatkan dan memotivasi keaktifan bertanya, menjawab, berpikir, dan bergerak siswa dalam pembelajaran, serta mengontrol perilaku negatif siswa (menanamkan nilai-nilai positif pada siswa).
Metode Progress Cards merupakan sebuah metode pembelajaran penjas inovatif yang dikembangkan dari metode latihan dengan tahapan-tahapan kegiatan latihan memodifikasi dari lima tahapan latihan pada "Practical Guidelines: Educational Cards Kids' Athletics" (Gozzoli, dkk, 2006 : 64-69) dengan menambahkan alat bantu motivasi progress cards (kartu kemajuan) sebagai usaha untuk mengembangkan kreatifitas, inisiatif dan motivasi berpikir siswa serta untuk meningkatkan kemampuan gerak dasar siswa secara bertahap dan kontinu.

Bentuk Penilaian Progress Card

Alat bantu progress cards sendiri adalah suatu alat bantu motivator dalam pembelajaran penjas dengan menggunakan sebuah kartu berisi penilaian-penilaian terhadap peningkatan hasil belajar yang dicapai setiap peserta dalam satu materi pembelajaran. Bentuk penilaiannya dapat berupa simbol ( atau ) yang menarik bagi siswa, sehingga siswa akan termotivasi untuk berusaha mendapatkan simbol tersebut dengan melakukan kegiatan pembelajaran secara sungguh-sungguh.

Simbol to sebagai pengganti nilai 2 sedangkan simbol $\triangle$ sebagai pengganti nilai 1. Penjelasannya yaitu untuk kolom penilaian psikomotor yang lebih pada keterampilan siswa, penilaian ini diberikan ketika guru meminta siswa untuk melakukan suatu gerakan dan gerakan tersebut dapat dilakukannya dengan benar, maka siswa tersebut mendapat nilai 2 namun apabila siswa tidak dapat melakukannya dengan benar maka siswa di beri nilai 1.

Sedangkan untuk kolom penilaian kognitif jika siswa dapat menjawab pertanyaan dari guru mengenai materi yang disampaikan maka mendapat nilai 2 namun yang tidak menjawab mendapatkan nilai 1 .

Untuk penilaian afektif berbeda, apabila pada saat proses pembelajaran siswa menyimpang dari perilaku positif maka satu kolom di beri symbol (silang), apabila siswa berperilaku positif maka di beri simbolV (contreng).

Yang menarik disini kenapa siswa yang tidak dapat melakukan keterampilan dengan baik dan juga tidak mampu menjawab pertanyaan dari guru tetap mendapatkan simbol 
dan nilai, hal ini bertujuan guna menghargai usaha yang dilakukan siswa. Dengan begitu siswa akan lebih lagi termotivasi untuk memperbaiki nilai yang telah diraih. Simbol yang di raih siswa akan di pasang di dada siswa, kecuali untuk penilaian afektif simbol tidak dipasang di dada, hal ini untuk menjaga psikologi siswa.

Namun apabila peniliaian kognitif dan psikomotor digunakan dalam permainan yang diperuntukan untuk dua kelompok/anak yang saling mengalahkan, maka kelompok/anak yang kalah dapat nilai 1 dan kelompok/anak yang menang dapat nilai 2 .

Berikut gambar kartu kemajuan tersebut:

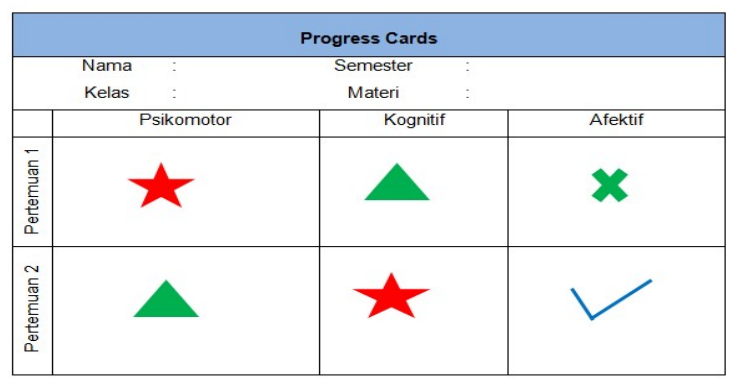

Pengertian Circuit Training

Menurut M. Sajoto (1995:83) latihan sirkuit adalah suatu program latihan terdiri dari beberapa stasiun dan di setiap stasiun seorang atlet melakukan jenis latihan yang telah ditentukan. Satu sirkuit latihan dikatakan selesai, bila seorang atlet telah menyelesaikn latihan di semua stasiun sesuai dengan dosis yang telah ditetapkan.

Menurut Soekarman (1987: 70) latihan sirkuit adalah suatu program latihan yang dikombinasikan dari beberapa item-item latihan yang tujuannya dalam melakukan suatu latihan tidak akan membosankan dan lebih efisien. Latihan sirkuit akan tercakup latihan untuk:1) kekuatan otot, 2) ketahanan otot, 3) kelentukan, 4) kelincahan, 5) keseimbangan dan 6) ketahanan jantung paru. Latihan-latihan harus merupakan siklus sehingga tidak membosankan. Latihan sirkuit biasanya satu sirkuit ada 6 sampai 15 stasiun, berlangsung selama 10-20 menit. Istirahat dari stasiun ke lainnya 15-20 detik.

Menurut Setiawan (2010:32), mengungkapkan bahwa latihan sirkuit dapat mengembangkan kondisi fisik seperti daya tahan, kelentukan, kelincahan, dan kekuatan. Satu kali latihan dalam setiap stasiun dilakukan 30 detik dan satu sirkuit dilakukan 15-20 menit. Kemudian istirahat antar stasiun adalah 15-20 detik, dan istirahat satu sirkuit 1-3 menit.

Ladder Drill

Ladder Drill merupakan suatu bentuk alat latihan untuk melompat menggunakan kaki dengan cara melompati tali berbentuk seperti tangga yang diletakkan di tanah atau lantai. Menurut Lee Brown \& Vance Ferrigno, dalam bukunya Training For Speed, Agility, And Quickness untuk dapat meningkatkan kecepatan, kelincahandan koordinasi salah satunya dapat dengan menggunakan alat ladder. Ladder drill adalah salah satu bentuk alat latihan fisik yang fungsinya melatih kelincahan kaki dan sinkronisasi gerak secara seimbang. Ladder drill juga bisa dikatakan sebagai tangga yang digunakan untuk meningkatkan kegesitan, kelincahan dan kecepatan gerak. Dengan berlatih tangga ketangkasan akan membantu meningkatkan berbagai aspek gerakan dasar olahraga seperti dalam meningkatkan keseimbangan tubuh, gerakan reflex, daya tahan otot, kecepatan reaksi dan koordinasi antar bagian tubuh. Selain manfaat fisik, latihan tangga ketangkasan secara berkesinambungan akan membantu dalam meningkatkan sistem saraf, stamina tubuh dan kekuatan otot kaki. Untuk berlatih gerak ini yang dibutuhkan adalah alat yang meyerupai anak tangga yang di letakkan pada bidang datar( Brown, Lee E.et al, $2000: 65$ ).

\section{METODE PELAKSANAAN}

Metode pelaksanaan kegiatan ini adalah dengan melaksanakan pelatihan tentang pembelajaranpenjas yang menarik dengan metode progress card melalui circuit training dan ladder drill.Kegiatan dilakukan 2 (dua) kali pertemuan dalam sebulan. Pertemuan pertama diberikan penjelasan tentang pembelajaranpenjas yang menarik dengan metode progress card melalui circuit training dan ladder drill. Setelah itu melakukan demonstrasi pembelajaran penjas. Kemudian para mahasiswa diharapkan mempraktekkan pembelajaran yang menarik dengan metode progress card melalui circuit training dan ladder drill. 
Selanjutnya mahasiswa diberi tugas untuk membuat sebuah simulasi pembelajaran penjas yang menarik dengan metode progress card melalui circuit training dan ladder drill. Pada pertemuan kedua, evaluasi tugas mahasiswa tentang pembelajaran yang menarik dengan metode progress card melalui circuit training dan ladder drill berupa praktek secara langsung. Untuk mengetahui sejauh mana pengetahuan dan pemahaman para mahasiswa dalam membuat pembelajaran penjas yang menarik dengan metode progress card melalui circuit training dan ladder drill.

\section{PELAKSANAAN DAN HASIL EVALUASI} Pelaksanaan

Kegiatan program pengabdian kepada masyarakat yang dilaksanakan selama dua hari, dengan acara tatap muka dan praktek berjalan dengan baik dan lancar. Pertemuan hari pertama dilakukan secara cara tatap muka dengan menggunakan metode ceramah, demonstrasi dan tanya jawab. Kemudian dihari kedua dilakukan secara praktek dengan metode microteaching. Kegiatan ini dilaksanakan pada tanggal 13-14 September 2019 yang didikuti oleh 76 orang. Pelaksanaan kegiatan dimulai pada pukul $07.00-11.00$ WIB. Kegiatan berupa teori bertempat di Laboratorium Olahraga PJKR FKIP UPR, sedangkan kegiatan berupa praktek dilakukan di lapangan PJKR FKIP UPR.

\section{Hasil dan Evaluasi}

Kegiatan pelatihan pembelajaran penjas yang menarik dengan metode progress card melalui circuit trainingdan ladder drill ini merupakan proses pelatihan yang hasilnya dapat langsung dilihat disaat para peserta mempraktekkan tugasnya dihadapan peserta lainnya. Selain itu juga kegiatan ini dapat dikatakn berhasil, apabila setelah kegiatan para pesertayang notabene merupakan calon guru pendidikan jasmani menerapkan metode ini baik disaat mengerjakan tugas perkuliahan yang serumpun serta disaat mereka nanti mengajar di sekolah. Dalam kegiatan ini peserta antusias mengikuti pelatihan, hal ini dapat dilihat dari perhatian peserta disaat memperhatikan dan menyimak pemateri memberikan pemaparan secara teori maupun demonstrasi, selain itu juga begitu banyak pertanyaan-pertanyaan yang dilontarkanpeserta disaat sesi tanya jawab. Kemudian disaat peserta diberikan tugas untuk membuat sebuah circuit training yang menarik dengan metode progress card melalui circuit trainingdan ladder drill, mereka cukup berhasil. Hal ini dapat dilihat disaat para peserta menjelaskan dan mendemonstrasikannya kepada peserta lainnya. Selain itu juga bahwa peserta merasa senang mengiktui pelatihan ini karena menambah wawasana mereka tentang metode suata proses pembelajaran terutama dalam pendidikan jasmani. Dan juga dengan pelatihan ini peserta merasa bahwa kreativitas mereka dirangsang kembali dalam mengerjakan tugas yang telah diberikan. Evaluasi dari kegiatan ini yaitu masih kurangnya referensi peserta tentang circuit training sebelum pelatihan.

\section{KESIMPULAN}

Kegiatan pengadbdian kepada pembelajaran penjas yang menarik dengan metode progress card melalui circuit trainingdan ladder drill ini sangat penting bagi pengenalan dan pemahaman pesertatentang metode-metode yang digunakan dalam proses pembelajaran. Terlebih pemateri menyajikan pemaparan secara rinci dan mendalam sehingga para peserta dengan mudah memahami dan mempraktekkannya. Selain itu juga bahwa seluruh peserta menyambut baik kegiatan pelatihan ini, karena belum pernah mengikuti dan melaksanakan kegiatan semacam ini sebelumnya.

\section{SARAN}

Berdasarkan kesimpulan dari pelatihan pembelajaran penjas yang menarik dengan metode progress card melalui circuit trainingdan ladder drill ini, maka sangat perlu untuk diselenggarkan kegiatan pelatihan ini secara rutin dan berkelanjutan supaya dapat menghasilkan sumber daya manusia yang unggul, terkhusus menjadi calon-calon guru pendidikan jasmani yang memiliki kualitas baik. 


\section{DAFTAR PUSTAKA}

A.M Bandi Utama. (2011). Pembentukan Karakter Bermain Anak Melalui Aktivitas Bermaian Dalam Pendidikan Jasmani. Yogyakarta : Jurusan Pendidikan Olahraga. FIK. UNY.

Brown, Lee E.et al. (2000). Training for Speed, Agility and Quikness. Champaign,IL : Human Kinetics.

Helmi Firmansyah. (2009). Hubugan Motivasi Berprestasi Siswa dengan Hasil Belajar Pendidikan Jasmani. Jurnal JPJI.

Jihad, Asep. (2012). Evaluasi Pembelajaran. Yogyakarta : Multi Pressindo

M. Sajoto. (1995). Peningkatan dan Pembinaan Kekuatan Kondisi Fisik dalam Olahraga. Semarang: Dahara Prize.

Rosdiani, Dini. (2013). Model Pembelajaran Langsung Dalam Pendidikan Jasmani dan Kesehatan. Bandung: Alfabeta.

Sagala, Syaiful. (2011), Konsep dan Makna Pembelajaran. Bandung: Alfabeta.

Setiawan. (2010). Peningkatan Kondisi Fisik.Jakarta: Nuha Medika

Solihin, D. M., Faisal, A., \& Dadang, S. (2013). Kaitan antara Status Gizi, Perkembangan Kognitif, dan Perkembangan Motorik pada Anak Usia Prasekolah. Penelitian Gizi dan Makanan.36(1), 62-72.

Sriawan, dkk. (2011). Pelatihan Pembelajaran Penjas yang Menarik dan Menggembirakan melalui Metode Bermain Berdasarkan Kurikulum Tingkat Satuan Pendidikan (KTSP) bagi Guru Penjas Sekolah Dasar di Kabupaten Bantul. Yogyakarta : Fakultas Ilmu Keolahragaan. UNY.

Sugihartono, dkk. (2013). Psikologi Pendidikan. Yogyakarta: UNY Press.

Suroto. (2008). Video Pembelajaran Penjasorkes Inovatif: Aktifitas Pengembangan. Surabaya: Tim Balitbang Diknas Mapel Penjas.

Wragg, E.C. (2012). Classroom Teaching Skill. Nicholas Publishing Company (Belajar dan Pembelajaran). Bandung: ALFABETA 